\title{
Performance, Intestinal Microbial Population, Immune and Physiological Responses of Broiler Chickens to Diet With Different Levels of Silver Nanoparticles Coated on Zeolite
}

\section{Niloofar Bolandi}

Gorgan University of Agricultural Sciences and Natural Resources https://orcid.org/0000-0003-35482305

Seyed Reza Hashemi ( $\nabla$ hashemi711@yahoo.co.uk)

Gorgan University of Agricultural Sciences and Natural Resources https://orcid.org/0000-0002-6716$083 X$

\section{Daryoush Davoodi}

ABRII: Agricultural Biotechnology Research Institute of Iran https://orcid.org/0000-0001-6369-241X

\section{Behrouz Dastar}

Gorgan University of Agricultural Sciences and Natural Resources https://orcid.org/0000-0002-57104770

\section{Saeed Hassani}

Gorgan University of Agricultural Sciences and Natural Resources https://orcid.org/0000-0002-11250625

\section{Amin Ashayerizadeh}

Gorgan University of Agricultural Sciences and Natural Resources https://orcid.org/0000-0003-4679$876 \mathrm{X}$

\section{Research}

Keywords: Silver nanoparticle, Zeolite, Humoral immune system, Microflora, Broiler

Posted Date: December 14th, 2020

DOl: https://doi.org/10.21203/rs.3.rs-125469/v1

License: (a) (1) This work is licensed under a Creative Commons Attribution 4.0 International License. Read Full License 
Version of Record: A version of this preprint was published at Italian Journal of Animal Science on January 1st, 2021. See the published version at https://doi.org/10.1080/1828051X.2021.1892546. 


\section{Abstract}

Background: The aim of this study was to evaluate the effects of different levels of silver nanoparticles coated on zeolite on performance, gastrointestinal microflora, heterophile to lymphocyte ratio and humoral immune system responses of broiler chickens. Three hundred seventy five Cobb 500 in a completely randomized design were distributed to 5 experimental diets: control diet, $1 \%$ zeolite, $0.25 \%$, $0.50 \%$ and $0.75 \%$ of silver nanoparticles coated on $1 \%$ zeolite. Performance traits were recorded and Blood samples were taken to determine antibody response against Newcastle on d 14, infectious bursal disease (Gumboro) on d 21 and Serum immunoglobulins (IgY, IgM, and IgA) were determined on d 42. Heterophile to lymphocyte ratio was evaluated on days 28,35 and 42 . At the end of $d 21$ and $d 42$.

Results: The result showed that feed conversion ratio was significantly improved in silver nanoparticle treatments compare with the control group $(p<0.05)$. Total anaerobic bacteria and the population of E.coli in ileum and cecum were decreased $(p<0.05)$. The highest number of lactobacillus was observed in NS50 $(p<0.05)$. Antibody response against Gumboro was decreased as well as the amount of IgY antibody in silver nanoparticles treatments. Significant differences were observed in heterophile to lymphocyte ratio on d 28 and 35 and the highest amount was observed in NS50 group $(p<0.05)$.

Conclusions: In conclusion, using silver nanoparticle dietary coated on zeolite could improve gut microflora, but silver nanoparticles could also have harmful side effects on the immune mechanism of broiler chickens.

\section{Background}

Intensive poultry farming and industrial poultry production has been achieved from the second half of the 20th by shortening the productive cycle and increasing the production capacity. In the past 50-60 years, the most important goal of broiler breeding is to increase profitability of broiler meat production and most achieved in poultry have been on performance traits. High intensity poultry production requires fast growing strains, usually at high stocking densities. With this type of husbandry, flocks are highly susceptible to disease. Studies with wild birds showed that increased productive effort reduces specific immune responses, parasite resistance, and parent survival (Van der Klein et al. 2015). It was determined that genotypes with higher body weight have weaker antibody response than lower body weight line of broilers (Boa-Amponsem et al. 2000).

On the other hand, gastrointestinal tract and the gut microbial ecosystem with $10^{7}$ to $10^{11}$ bacteria per each gram play vital roles in nutrition absorption, development of immunity, and disease resistance (Pickard et al. 2017). Alterations in the microbial community may have adverse effects on feed efficiency, productivity, and health of chickens (Wu and Wu 2012). It was also observed that the gut microbial population can promote the migration of mast cells into the intestine (Kunii et al. 2011). Gut microbial population was also found to be the major driving force to produce mucosal IgA (Crabbé et al. 1968). 
During the last few decades, antibiotics have been widely used as growth promoters to improve feed efficiency and animal growth through the modulation of gut microbial population and the host's immune system. The ban on antibiotics for growth promotion within the European Union in 2006, caused more interests in finding alternatives to antibiotics in poultry production (Torok et al. 2011).

Therefore, any factor and approach that can improve this microbial ecosystem could be considered as immunomodulators and also, one of several approaches to increase immune responsiveness in high intensity production in poultry is to supplement rations with feed additives (Rauw 2010; Hashemi and Davoodi 2012). The common feed additives used in poultry industry are herbal plants, antioxidants, emulsifiers, binders, enzymes, pH control agents, probiotics and prebiotics (Hashemi and Davoodi 2014).

Recently, using silver as an alternative antimicrobial agent has been noticed by researchers. Metallic silver compounds and silver ions have been known to have unique antibacterial properties for a long time. It has been used since ancient times to treat burns, wounds and bacterial infections (Rai et al. 2009). Nanotechnology is one of the newest branches of science that make it possible to manufacture silver in the nano size (1-100 nm). Nanoparticles are more reactive that larger particles because of the larger surface area and exposing more atoms on the surface of them. Furthermore, silver nanoparticles (Ag-NPs) have unique biological properties and broad-spectrum antibacterial activity against microorganisms (Lara et al. 2010). Because of these strong abilities of silver nanoparticles to eliminate bacteria, and disability of pathogens to resist against these particles, it is supposed that Ag-NPs may affect microbial populations of gastrointestinal tract and hereby may improve immune system and productive purposes (Varner et al. 2010).

In addition to antimicrobial properties, Ag-NPs are capable to carry oxygen molecules at the cellular level. The oxygen fits and accumulates in the octahedral holes of Ag-NPs may increase anabolic activity and subsequently stimulate growth and development (Pineda et al. 2012). Also, it is has been reported the use of the Ag-NPs in poultry have great potential (Sawosz et al. 2007) but there are only a few investigations regarding the use of silver nanoparticles and zeolite in poultry nutrition.

Also, zeolites are crystalline aluminosilicates with physicochemical effects such as permitting ion exchange, absorption, diffusion, molecular sieving, dehydration, reversible dehydration and catalysis that caused using of these products in animal nutrition (Eleroglu and Yalçin 2005). Mallek et al (2012) reported that supplementing zeolite to broiler diets has positive effects on performance, organoleptic parameters and mainly increased level of Omega 3 fatty acid. Besides, silver nanoparticles coated on zeolite were demonstrated to use as feed additives in several studies because of their positive effects on meat quality, feed conversion ratio and hepatic enzymes of broiler chickens (Hashemi et al. 2014).

Thus the aim of this experiment was to study the effects of silver nanoparticles coated on zeolite on microbial community composition of ileum and cecum, heterophile to lymphocyte ratio as an index of stress, humoral immunity and morphometric analysis of the gut in broiler chickens. 


\section{Methods}

\section{Diet and feeding}

A total of 375 one-day-old (Cobb 500) broiler chicks (half male and half female) were obtained from a local commercial hatchery. Broilers were vaccinated for infectious bronchitis (on d 1), Newcastle disease (on d 7), and Gumboro live vaccine (on d 14). Chickens were randomly allocated in 5 experimental treatments for 6 weeks. Each treatment arranged in 5 replicated of 15 broilers each. All procedures were approved by the ethics committee for animal experiments at the Gorgan University of Agricultural Sciences and Natural Resources, Gorgan, Iran. The temperature was regulated at $32 \pm 1^{\circ} \mathrm{C}$ during the first week and it decreased $1^{\circ} \mathrm{C}$ every 3 days. The temperature was fixed at $23 \pm 1^{\circ} \mathrm{C}$ for the rest of the experiment. The experimental treatment diets were:

1. Basal diet without any addition (C).

2. Basal diet containing $1 \%$ zeolite (Z).

3. Basal diet containing $1 \%$ zeolite coated with 25 ppm Ag-NPs (NS25).

4. Basal diet containing $1 \%$ zeolite coated with 50 ppm Ag-NPs (NS50).

5. Basal diet containing 1\% zeolite coated with 75 ppm Ag-NPs (NS75).

The zeolite that used in this experiment obtained from well-defined zeolitic stratigraphic units from the region of Semnan province, Iran. Zeolitic rock was pulverized and sieved to make particles in the size of 1-2 mm. distilled water was used to wash and remove contaminations from the particles and subsequently dried at $105^{\circ} \mathrm{C}$ all over the night in the oven. The chemical formula of pure zeolite was $\left(\mathrm{K}_{2}\right.$, $\left.\mathrm{Na}_{2}, \mathrm{Ca}, \mathrm{Mg}\right)_{3} \mathrm{Al}_{6} \mathrm{Si}_{30} \mathrm{O}_{72}$. $24 \mathrm{H}_{2} \mathrm{O}$.

Nanosized silver particles (Ag-NPs) with a maximum diameter of $50 \mathrm{~nm}$ was coated on zeolite and received as a gift from Dr. D. Davoodi at Agricultural Biotechnology Research Institute of Iran (ABRII), (Karaj, Iran). Briefly, the preparation of coating method on zeolite with desired properties was that the zeolite was first stirred in distilled water with a stirrer, and then, the prepared nanosilver $(20-50 \mathrm{~nm})$ with the desired percentage added to the mixture after adjusting the $\mathrm{pH}$ and Stirring was continued for a further $30 \mathrm{~min}$ at $15^{\circ} \mathrm{C}$. The stabilizers were gradually added to the mixture and stirred until the resulting mixture color became brown. After settling of the precipitate dried at ambient temperature.

Zeolites were analyzed by X-ray Fluorescence (XRF) technique to determine their chemical composition and the XRF data collected on a PHILIPSPW1480 XRF spectrometer with Rh tube (Nikpey et al. 2013) (Table 1). The morphology studied by Field emission scanning electron microscopy (FESEM, Mira, 3$\mathrm{XMU}$ ) and the materials composition investigated by energy dispersive X-ray spectroscopy (EDX) and elemental mapping analyses at Razi Metallurgical Research Center, Iran (Fiure 1). To measure the silver ( $\mathrm{Ag})$ content of zeolite we used the method described by Kulthong et al (2010). Briefly, 0.2-0.3 g of sample digested in $5 \mathrm{~mL}$ of $14.4 \mathrm{M} \mathrm{HNO}_{3}$ by a microwave digestion system to dissolve all the silver content. The microwave irradiation cycles were $250 \mathrm{~W}$ (5 min), $400 \mathrm{~W}$ (5 min), and $600 \mathrm{~W}$ (5 min). Then the digested 
sample was cooled and diluted up to $25 \mathrm{~mL}$ with deionized water to enable quantification of silver by a graphite furnace atomic absorption spectroscopy or GFAAS (Perkin Elmer Analyst 300, Waltham, MC).

The basal diet was in mash form and formulated for starter (1 to 21 day), and grower (22 to 42 day) periods. The composition and ingredients of basal diets are shown in table 2. Birds had free access to feed and water.

\section{Sample collection and measurement}

Feed consumption was recorded a weekly basis, by monitoring the feed offered and amounts remained at feeders at the end of the week. Individual bird weight was also recorded weekly. Feed conversion ratio (FCR) was calculated as the following: FCR = average feed consumed/average live weight. On d 21 and 42 , two birds of each replication were killed. The gastrointestinal tract was removed and immediately the contents of the cecum and ileum were diluted 10-fold using sterile Phosphate Buffer Solution (BPS) (pH 7.0) and homogenized on a vortex for $3 \mathrm{~min}$. the dilution continued serially for each sample from $10^{-1}$ to $10^{-9}$ and then subsequently plated to the enumeration of bacterial groups.

Total anaerobes, Lactobacillus and Escherichia coli were enumerated respectively using duplicated plate count agar (PCR), MRS agar and Mac Conkey agar according to tuohy et al (2002). Anaerobic incubation was achieved using sealed anaerobic jars. The plates were incubated at $37^{\circ} \mathrm{C}$ for 24 to $72 \mathrm{~h}$ and then the numbers of colonies were counted. The results of the experiment were expressed as $\log _{10}$ colony-forming units per each gram of digested content of the intestine.

A total of 50 birds [10 birds per treatment] was used for determining the proportion of heterophile to lymphocyte $(\mathrm{H} / \mathrm{L})$ as an index of stress on $\mathrm{d} 28$, 35vand 42 . Blood samples $(1-2 \mathrm{ml})$ were collected from the wing vein and immediately transferred to heparinized containers. Two drops of blood samples placed on the slide and a blood smear were made. After drying stained with Wright-Giemsa stain. Samples were examined under a compound microscope (Nikon, Eclipse E200-LED) (Carroll et al. 1996). Standard avian guidelines for manual hematology were used to identify cells. Heterophils and lymphocytes were counted to a total of 100 cells.

The titer of antibody activity against Newcastle disease measured by conventional Hemagglutination Inhibition ( $\mathrm{HI}$ ) assay on $\mathrm{d} 14$ (7 d after postimmunizition). $\mathrm{HI}$ assay was done according to the procedure of OIE and the titers of antibodies against Gumboro were measured on $\mathrm{d} 21$ ( $7 \mathrm{~d}$ after postimmunizition) using a commercial Enzyme linked immuno sorbent assay (ELISA) kit (Razi Company; Arak, Iran). To measure the amount of plasma immunoglobulin, blood samples were collected from the wing vine on $d$ 42 and centrifuged at $2000 \mathrm{rpm}$ for $10 \mathrm{~min}$. Blood plasma stored at $-20^{\circ} \mathrm{C}$ for further analysis. The concentrations of immunoglobulin $\mathrm{Y}, \mathrm{M}$ and $\mathrm{A}$ ( $\lg \mathrm{Y}, \lg \mathrm{M}$ and $\lg \mathrm{A}$ ) were measured by commercial ELISA kits (Kamiya Biomedical Company).

\section{Statistical analysis}


All data were initially checked for normality and homogeneity of variance using Bartlett and KolmogorovSmirnov tests. All bacteria enumeration data were transformed to $\log _{10} \mathrm{CFU} / \mathrm{ml}$. Statistical analyses were subjected to ANOVA using the General Linear Model procedure (GLM) (SAS 2003). When significant differences occurred $(p<0.05)$, means were separated by Tukey's Studentized range test (SAS 1989).

\section{Results}

The effect of dietary treatments on performance traits including body weight and feed intake indicates that diet containing silver nanoparticles and zeolite have not significant difference with the control group $(p>0.05)$. Moreover, feed conversion ratio was significantly higher in silver nanoparticle treatments compare with the control group $(p<0.05)$. The population of total anaerobes bacteria of ileum on $\mathrm{d} 21$ did not show any significant difference between treatments, while it significantly decreased on day 42 in NS75. The total anaerobes bacteria of cecum on $\mathrm{d} 21$ and 42 days of age significantly affected by experimental diets, and decreased compared to the control group. Moreover, the number of E. coli bacteria was also decreased in both ileum and cecum of broiler chickens on $\mathrm{d} 21$ and 42 . The population of Lactobacillus of ileum was affected by experimental treatments. At 21 and 42 days of age, the highest total count of Lactobacillus sp. was observed in NS50 treatment $(p<0.05)$.

The ratio of H/L on day 28 increased in both NS50 and NS75. It was also increased on d 35 in NS50 significantly.

Experimental treatments did not have any significant effect on the titer of antibody against Newcastle but Ag-NPs significantly decreased antibody against Gumboro compared to the control diet. Moreover, the concentration of IgY and IgA of plasma significantly decreased by increasing the level of Ag-NPs while the amount of IgM did not show any significant difference.

\section{Discussion}

Many studies have demonstrated the antibacterial activity of Ag-NPs even in low concentrations (Rai et al. 2009). The mechanisms of action of Ag-NPs on bacteria are not totally investigated yet but it is known that silver binds with sulfur-containing proteins of the bacterial cell wall and cell membrane and inhibits the respiration process (Slavin et al. 2017). Moreover, silver ions interact with the phosphorus containing compounds like DNA and inhibit replication (Silver et al. 2006). It has also been attributed that Ag-NPs can inactive phosphomannose isomerase enzyme. This enzyme catalyzes the conversion of mannos-6phosphate to fructose-6-phosphate which is an important intermediate of glycolysis as the most common pathway in sugar catabolism of bacteria. Moreover, in the E. coli bacteria, some holes in the cell membranes were observed after contact with Ag-NPs (Choi and Hu 2008).

In addition, Pineda et al (2012) reported that in ovo injection of silver nanoparticles reduced feed intake and body weight gain in chickens however, no concurrent effect on feed conversion ratio was observed. 
Although there is no negative effects on feed intake has been reported as a result of silver nanoparticle supplementation in the feed or via the drinking water (Pineda et al. 2012; Ahmadi 2012).

In agreement with other researches, Sawosz et al (2007) reported that when a diet supplemented with 25 $\mathrm{mg} / \mathrm{kg}$ Ag-NPs the number of gram-positive bacteria (Lactobacillus spp, Leuconostoclactis, Actinomycesnaes/undii) significantly increased compared to the control group in quails. The number of Streptococcus boviscolonies in samples taken from quails receiving $25 \mathrm{mg} / \mathrm{kg}$ Ag-NPs increased. However, Ag-NPs did not influence the population of Enterococcus faecium. There was no significant effect on the number of $E$. coli and other Enterobacteriaceae.

Exact mechanism of nanoparticle synthesis in biological systems was not completely described. The mechanism of intracellular and extracellular production differs from one organism to another.

Therefore, as it was observed in this study the population of anaerobic bacteria was decreased which are sensitive to oxygen concentration while the colonies of lactic acid bacteria (non-obligatory anaerobic), increased in competition with anaerobes (Singh et al. 2008). Moreover, it was shown that gram-negative bacteria are more sensitive to treatment with nanoparticles (Coccini et al. 2013) that can explain the reason for significant reduction in $E$. coli. Moreover, in this study, the amount of $\mathrm{H} / \mathrm{L}$ ratio increased significantly in NS50 (Days 28 and 35 of age) and NS75 (Day 35 of age).

It has been shown that nanoparticles can induce oxidative stress. There are several keys factors involved in inducing reactive oxygen species (ROS) by nanoparticles: 1) pro-oxidant groups that exist on the surface of nanoparticles; 2) redox cycle on the surface of nanoparticles due to transition metal-based NP; and 3 ) interactions of particle cells. ROS have strong bactericidal activities but they may also hurt body cells as well and induce apoptosis in the body tissues (Coccini et al. 2013).

It was reported that silver nanoparticles can cause apoptosis via the mitochondrial pathway by generating ROS and activating c-Jun N-terminal kinase (JNK) (Hsin et al. 2008). Accumulation of ROS can cause inflammatory response, perturbation and destruction in mitochondria.

Lovric et al (2005) reported that Ag-NPs entered blood systemic circulation after absorption from GIT. These particles are capable to interact with different metabolites like plasma proteins, platelets, red and white blood cells, and coagulation factors. In this way, silver nanoparticles can induce oxidative stress by changing the structure and physiological characteristics of cells.

Ahmadi (2012) showed that 20, 40 and $60 \mathrm{ppm}$ of Ag-NPs significantly increase the activity of oxidative enzymes such as catalase (CAT), superoxide dismutase (SOD) and glutathione peroxidase (GPX).

Moreover Ag-NPs can cause damage to different organs and tissues like liver cells.

It was demonstrated that stressors, such as food or water deprivation, temperature extremes, constant light, and exposure to novel social situations increase a number of heterophils while decrease lymphocytes. The mechanisms of these changes in the number of immune cells of birds are not clearly 
known, but it may due to the effects of stress on the adrenal corticotropic hormone and corticosterone and cytokines.

The results of this study indicated that Ag-NPs is an stressor factor in young chickens (d 28 and 35) but it did not affect the $\mathrm{H} / \mathrm{L}$ ratio at the age of $42 \mathrm{~d}$. Toxicity effects of Ag-NPs was studied in the zebrafish embryonic model. The results showed that all sizes of colloidal Ag-NPs (3, 10, 50 and $100 \mathrm{~nm})$ could induce toxicity and the rate of mortality increased by size reduction of particles $(80 \%, 64 \%, 36 \%$, and $3 \%$ respectively). Overall, there are other different parameters that can be responsible for toxicity of Ag-NPs, such as, concentration, stability and chemistry.

Similar to the results of this study in humoral immunity parameter, Pineda et al (2012) reported that the concentration of plasma IgY reduced by using 10 and 20 ppm of Ag-NPs.

Vadalasetty et al (2018) also showed that the concentration of IgY and IgM were lower in the chickens received Ag-NPs compared to the control group. The reason for reduction in the levels of $\lg Y$ and IgA in this study might be due to the changes in microbial colonization occurred by Ag-NPs received from the diet. Ag-NPs may impair intestinal transportation of nutrients such as sugar, amino acids, trace elements and vitamins and the deficiency of nutrients can decrease antibody formation.

In addition, this event might be due to the effects of Ag-NPs on lymphoid organs such as bursa and spleen (Elkloub et al. 2015). Grodzik and Sawosz (2006) determined that $10 \mathrm{ppm}$ of Ag-NPs had no effect on chickens' growth but reduced the number and size of the lymph follicles in the bursa of fabricius.

Bursa is one of the most important organs related to the immune system by producing B-lymphocyte. It is the first lymphoid organ that is responsible for the establishment and maintenance of B-lymphocyte compartment. Therefore using Ag-NPs can influence the amount of antibodies by affecting the quantity and the quality of B-lymphocytes.

Castillo et al (2008) showed that Tiopronin monolayer-protected Ag-NPs doesn't have any proinflammatory effects on macrophages while it can inhibit the secretion of IL- 6 by specific TLRs located on the cell membrane or in the endocytic compartments.

Furthermorem, Ag-NPs could significantly inhibit phytoheamagglitinin that induce cytokine production.

\section{Conclusions}

In conclusion, the results of the current study investigated that silver nanoparticles improved the gastrointestinal microflora properly. Despite its potential effect on digestive microbial biodiversity and function, other effects of nanosilver related to host physiological statuses, such as the immunological status and stress factors may negatively be influenced by silver nanoparticles.

\section{Declarations}




\section{Ethics approval and consent to participate}

This study obtained ethical clearance (Approval No: 97/20/1655) from the institutional animal care and use committee of Gorgan University of Agricultural Sciences and Natural Resources.

\section{Consent for publication}

Not applicable.

\section{Competing interests}

The authors declare that they have no competing interests.

\section{Funding}

This research was partially funded by a self-funded MSc student and also funded by the Gorgan University of Agricultural Sciences and Natural Resources, Gorgan, Iran.

\section{Authors' contributions}

Conceptualization: S. R. Hashemi

Literature search: N. Bolandi and S. R. Hashemi

Methodology: D. Davoodi, A. Ashayerizadeh and B. Dastar

Data analysis: S. Hassani

Writing original draft: N. Bolandi and S. R. Hashemi

Writing review and editing: S. R. Hashemi

\section{Acknowledgments}

This work was carried out with the support of the Vice Presidency of Research and Technology at the Gorgan University of Agricultural Science and Natural Resources. The authors would like to express their profound gratitude to Dr. D. Davoodi for nanomaterial synthesis and functionalization.

\section{References}

1. Ahmadi F. Impact of different levels of silver nanoparticles (Ag-NPs) on performance, oxidative enzymes and blood parameters in broiler chicks. Pak Vet J. 2012;32:325-8.

2. Boa-Amponsem K, Dunnington EA, Pierson FW, Larsen CT, Siegel PB. Antibody responses to different dosages of sheep red blood cells in lines of chickens selected for high and low antibody response to sheep red blood cells. Poult Sci. 2000;79:159-62. https://doi.org/10.1093/ps/79.2.159 
3. Carroll M, Tomasson M, Barker GF, Golub TR, Gilliland DG. The TEL-PDGF $\beta R$ fusion protein dimerizes and trans- forms hematopoietic cells through activation of PDGF $\beta$ R dependent signaling pathways. Proc Natl Acad Sci USA. 1996;93:14845-50. https://doi.org/1073/pnas.93.25.14845

4. Castillo PM, Herrera JL, Fernandez-Montesinos R, Caro C, Zaderenko AP, Mejías JA, et al. Tiopronin monolayer-protected silver nanoparticles modulate IL-6 secretion mediated by Toll-like receptor ligands. Nanomedicine. 2008;3:627-35. https://doi.org/10.2217/17435889.3.5.627

5. Choi $\mathrm{O}, \mathrm{Hu} Z$ Z. Size dependent and reactive oxygen species related nanosilver toxicity to nitrifying bacteria. Environ Sci Technol. 2008;42:4583-8. https://doi.org/1021/es703238h

6. Coccini T, Barni S, Vaccarone R, Mustarelli P, Manzo L, Roda E. Pulmonary toxicity of instilled cadmium-doped silica nanoparticles during acute and subacute stages in rats. Histol Histopathol. 2013;28:195-209. https://doi.org/14670/HH-28.195

7. Crabbé PA, Bazin H, Eyssen H, Heremans JF. The normal microbial flora as a major stimulus for proliferation of plasma cells synthesizing IgA in the gut The germ-free intestinal tract. Int Arch Allergy Appl Immunol. 1968;34:362-75. https://doi.org/10.1159/000230130

8. Eleroglu $\mathrm{H}$, Yalçin Use of natural zeolite- supplemented litter increased broiler production. S Afr J Anim Sci. 2005;35:90-7.

9. Elkloub K, El. Moustafa M, Ghazalah AA, Rehan AAA. Effect of dietary nanosilver on broiler performance. Int J Poult Sci. 2015;14:177-82. https://doi.org/1186/s12917-017-1323-x

10. Grodzik M, Sawosz E. The influence of silver nano particles on chicken embryo development and bursa of Fabricius morphology. J Animal Feed Sci. 2006;15:111-4.

https://doi.org/22358/jafs/70155/2006

11. Hashemi SR, Davoodi D, Dastar B, Bolandi N, Esmaeili M, Mastani R. Meat quality attributes of broiler chickens fed diets supplemented with silver nanoparticles coated on zeolite. Poul Sci J. 2014;2:18393. https://doi.org/22069/psj.2014.1965

12. Hashemi SR, Davoodi H. New antibiotic replacements as growth and health promoters. J Gorgan Univ Med Sci. 2012;13:1-10. [In Persian]

13. Hashemi SR, Davoodi H. New generation of natural bioactive compounds as immunostimulators. Global J Pure Appl Sci. 2014;4:48-50.

14. Hsin YH, Chen CF, Huang S, Shih TS, Lai PS, Chueh PJ. The apoptotic effect of nanosilver is mediated by a ROS- and JNKdependent mechanism involving the mitochondrial pathway in NIH3T3 cells. Toxicol Lett. 2008;179:130-39. https://doi.org/1016/j.toxlet.2008.04.015

15. Kulthong K, Srisung S, Boonpavanitchakul K, Kangwansupamonkon W, Maniratanachote R. Determination of silver nanoparticle release from antibacterial fabrics into artificial sweat. Part Fiber Toxicol. 2010;7:1-9. https://doi.org/1186/1743-8977-7-8

16. Kunii J, Takahashi K, Kasakura K, Tsuda M, Nakano K, Hosono A, Kaminogawa S. Commensal bacteria promote migration of mast cells into the intestine. J Immunol. 2011;216:692-7. https://doi.org/10.1016/j.imbio.2010.10.007 
17. Lara HH, Ayala-Núñez NV, IxtepanTurrent LC, Rodríguez Padilla C. Bactericidal effect of silver nanoparticles against multidrug-resistant bacteria. World J Microbiol Biotechnol. 2010;26:615-21. https://doi.org/1007/s11274-009-0211-3

18. Lovrić J, Bazzi HS, Cuie Y, Fortin GR, Winnik FM, Maysinger D. Differences in subcellular distribution and toxicity of green and red emitting CdTe quantum dots. J Mol Med. 2005;83:377-85. https://doi.org/1007/s00109-004-0629-x

19. Mallek Z, Fendri I, Khannous L, Ben Hassena A, Traore Al, Ayadi MA. Effect of zeolite (clinoptilolite) as feed additive in Tunisian broilers on the total flora, meat texture and the production of omega 3 polyunsaturated fatty acid. Lipids Heath Dis. 2012;11:35. https://doi.org/1186/1476-511X-11-35

20. Nikpey A, Kazemian H, Safari-Varyani A, Rezaei M, Sirati-Sabet M. Protective effect of microporous natural cli-noptilolite on leadinduced learning and memory impairment in rats. Zahedan J Res Med Sci. 2013;2:52-7. https://doi.org/17795/jhealthscope-10041

21. Pickard JM, Zeng MY, Caruso R, Núñez G. Immune response from a resource allocation perspective. Immunol Rev. 2017;279:70-89. https://doi.org/10.1111/imr.12567

22. Pineda L, Sawosz E, Lauridsen C, Engberg RM, Elnif J, Hotowy AM, et al. Influence of in ovo injection and subsequent provision of silver nanoparticles on growth performance, microbial profile, and immune status of broiler chickens. Access Anim Physiol. 2012;4:1-8. https://doi.org/2147/OAAP.S35100

23. Rai M, Yadav A, Gade A. Silver nanoparticles as a new generation of antimicrobials. Biotechnol Adv. 2009;27:76-83. https://doi.org/10.1016/j.biotechadv.2008.09.002

24. Rauw WM. Immune response from a resource allocation perspective. Front Genet. 2012;3:267. https://doi.org/10.3389/fgene.2012.00267

25. SAS Institute. 2003. SAS user's guide: Statistics. Version 9/1. SAS Institute Inc., Cary, NC.

26. SAS Institute. Inc. SAS user's guide. 6thed. SAS Institute Inc. Cary, NC. 1989.

27. Sawosz E, Binek M, Grodzik M, Zielińska M, Sysa P, Szmidt M. Influence of hydrocolloidal silver nanoparticles on gastrointestinal microflora and morphology of enterocytes of quails. Arch Anim Nutr. 2007;61:444-51. https://doi.org/1080/17450390701664314

28. Silver S, Phung LT, Silver Silver as biocides in burn and wound dressings and bacterial resistance to silver compounds. J Ind Microbiol Biotechnol. 2006;33:627-34. https://doi.org/10.1007/s10295-0060139-7

29. Singh M, Singh S, Prasad S, Gambhir IS. Nanotechnology in medicine and antibacterial effect of silver nanoparticles. Dig J Nanomater Biostruct. 2008;3:115-22.

30. Slavin YN, Asnis J, Häfeli UO, Bach H. Metal nanoparticles: understanding the mechanisms behind antibacterial activity. J Nanobiotechnology. 2017;15: https://doi.org/10.1186/s12951-017-0308-z

31. Torok VA, Allison GE, Percy NJ, Ophel-Keller K, Hughes RJ. Influence of antimicrobial feed additives on broiler commensal posthatch gut microbiota development and performance. Appl Environ Microbiol. 2011;77:3380-90. https://doi.org/10.1128/AEM.02300-10 
32. Tuohy KM, Ziemer CJ, Klinder A, Knöbel Y, Pool-Zobel BL, Gibson GR. A human volunteer study to determine the prebiotic effects of lactulose powder on human colonic microbiota. Microb Ecol Health Dis. 2002;14:165-73. https://doi.org/1080/089106002320644357

33. Vadalasetty KP, Lauridsen C, Engberg RM, Vadalasetty R, Kutwin M, Chwalibog A. Influence of silver nanoparticles on growth and health of broiler chickens after infection with Campylobacter jejuni. BMC Vet Res. 2018;14:1-11. https://doi.org/1186/s12917-017-1323-x

34. Van der Klein SAS, Berghof TVL, Arts JAJ, Parmentier HK, Van der Poel JJ, Bovenhuis H. Genetic relations between natural antibodies binding keyhole limpet hemocyanin and production traits in a purebred layer chicken line. Poult Sci. 2015;94:875-82. https://doi.org/10.3382/ps/pev052

35. Varner KE, El-Badawy A, Feldhake D, Venkatapathy R. State-of-the-science review: Everything nano silver and more. Washington DC: US environmental protection agency; 2010.

36. Wu JM, Wu E. The role of gut microbiota in immune homeostasis and autoimmunity. Gut Microbes. 2012;3:4-14. https://doi.org/10.4161/gmic.19320

\section{Tables}

Table 1. The summarized chemical composition of the used zeolite by means of $X$-ray Fluorescence $(\mathrm{XRF})^{1}$ technique.

\section{Constituents}

$\mathrm{SiO}_{2}$

$\mathrm{Al} 2 \mathrm{O} 3$

Fe2O3

$\mathrm{CaO}$

$\mathrm{Na} 2 \mathrm{O}$

$\mathrm{K} 2 \mathrm{O}$

$\mathrm{MgO}$

$\mathrm{TiO} 2$

$\mathrm{MnO}$

P205

SO3

L.O. $\left.\right|^{2}$

$\mathrm{Si} / \mathrm{Al}$

$\mathrm{Ag}^{3}$

\section{$\%$ by weight}

68.95

11.14

0.97

4.83

0.95

0.90

0.79

0.201

0.011

0.012

0.068

10.64

4.81

< 5ppm 
Semnan natural zeolite-rich tuffs.

${ }^{1}$ XRF PHILIPS PW1480 XRF spectrometer with Rh tube.

${ }^{2}$ LOI: loss on ignition.

${ }^{3}$ The silver content was measured by a graphite furnace atomic absorption spectros-copy (GFAAS). 


\begin{tabular}{|c|c|c|c|c|}
\hline \multicolumn{2}{|c|}{ Zeoilte diet } & \multicolumn{3}{|c|}{ Control diet } \\
\hline$(22-42)$ & $(1-21)$ & $(22-42)$ & $(1-21)$ & Ingredients (\%) \\
\hline 57.84 & 51.60 & 59.69 & 53.70 & Yellow corn \\
\hline 33.68 & 39.95 & 33.25 & 39.52 & Soybean meal ( $44 \% \mathrm{CP})$ \\
\hline 4.11 & 3.69 & 3.41 & 3.00 & Soybean oil \\
\hline 1.00 & 1.00 & 0 & 0 & Zeolite (Coated zeolite) \\
\hline 1.09 & 1.47 & 1.09 & 1.47 & Dicalcium phosphate \\
\hline 1.28 & 1.18 & 1.29 & 1.19 & Limestone \\
\hline 0.32 & 0.43 & 0.32 & 0.43 & Salt \\
\hline 0.25 & 0.25 & 0.25 & 0.25 & Vitamin premix $^{1}$ \\
\hline 0.25 & 0.25 & 0.25 & 0.25 & Mineral premix ${ }^{2}$ \\
\hline 0.05 & 0.13 & 0.05 & 0.13 & DL-Methionine \\
\hline \multirow[t]{2}{*}{0.13} & 0.05 & 0.13 & 0.06 & L-Lysine \\
\hline & & & & Chemical analysis \\
\hline 3050 & 2950 & 3050 & 2950 & $\mathrm{ME}(\mathrm{Kcal} / \mathrm{kg})$ \\
\hline 19.06 & 21.2 & 19.06 & 21.2 & $\mathrm{CP}(\%)$ \\
\hline 0.86 & 0.92 & 0.86 & 0.92 & $\mathrm{Ca}(\%)$ \\
\hline 0.33 & 0.41 & 0.33 & 0.41 & $\mathrm{~Pa}(\%)$ \\
\hline 0.14 & 0.18 & 0.14 & 0.18 & $\mathrm{Na}(\%)$ \\
\hline 0.95 & 1.01 & 0.95 & 0.01 & Lys (\%) \\
\hline 0.36 & 0.47 & 0.36 & 0.47 & Met (\%) \\
\hline 0.37 & 0.36 & 0.37 & 0.36 & Met + Cys (\%) \\
\hline
\end{tabular}

${ }^{1}$ Supplied per Kg of diet: Vitamin A, 1,500 IU; Cholecalciferol, 200 IU; Vitamin E, 10 IU; Riboflavin, 3.5 mg; Pantothenic acid, 10 mg; Niacin, 30 mg; Cobalamin, 10 mg; Choline chloride, 1,000 mg; Biotin, 0.15 mg; Folic acid, $0.5 \mathrm{mg}$; Thiamine $1.5 \mathrm{mg}$; Pyridoxine $3.0 \mathrm{mg}$.

${ }^{2}$ Supplied per Kg of diet: Iron, 80 mg; Zinc, 40 mg; Manganese, 60 mg; lodine, 0.18 mg; Copper, 8 mg; Selenium, $0.15 \mathrm{mg}$. 
Table 3. Effect of different treatments on body weight, feed intake and feed conversion ratio in broilers

\begin{tabular}{|c|c|c|c|}
\hline Treatments & Body weight (g) & Feed intake (g) & Feed conversion ratio \\
\hline & From d 1 to 21 & & \\
\hline C & 812.38 & 1270.00 & 1.56 \\
\hline $\mathrm{Z}^{1}$ & 816.12 & 1243.92 & 1.52 \\
\hline $\mathrm{NS} 25^{2}$ & 817.82 & 1199.68 & 1.46 \\
\hline NS50 3 & 836.36 & 1198.67 & 1.43 \\
\hline$N S 75^{4}$ & 831.04 & 1238.25 & 1.49 \\
\hline SEM $^{5}$ & 21.11 & 39.48 & 0.04 \\
\hline \multirow[t]{2}{*}{$P$-value } & .9117 & .6719 & .3136 \\
\hline & From d 22 to 42 & & \\
\hline C & 1376.82 & 3297.14 & $2.39^{a}$ \\
\hline$Z^{1}$ & 1507.44 & 3384.23 & $2.24^{b}$ \\
\hline $\mathrm{NS} 25^{2}$ & 1477.59 & 3105.34 & $2.10^{\mathrm{bc}}$ \\
\hline$N S 50^{3}$ & 1440.98 & 3102.57 & $2.09^{c}$ \\
\hline$N S 75^{4}$ & 1434.01 & 3124.82 & $2.18^{b c}$ \\
\hline SEM $^{5}$ & 45.19 & 96.30 & 0.04 \\
\hline \multirow[t]{2}{*}{$P$-value } & .3459 & .0772 & .0012 \\
\hline & From d 1 to 42 & & \\
\hline C & 2189.21 & 4567.1 & $2.08^{a}$ \\
\hline$Z^{1}$ & 2323.55 & $4628 / 0$ & $1.99^{b}$ \\
\hline $\mathrm{NS} 25^{2}$ & 2295.41 & 4204.9 & $1.87^{\mathrm{c}}$ \\
\hline$N S 50^{3}$ & 2277.34 & 4211.04 & $1.84^{c}$ \\
\hline$N S 75^{4}$ & 2265.05 & 4363.1 & $1.92^{\mathrm{bc}}$ \\
\hline SEM $^{5}$ & 50.28 & 104.43 & 0.02 \\
\hline$P$-value & .43 & .05 & .00 \\
\hline
\end{tabular}


${ }^{1}$ Diet containing $1 \%$ Zeolite; ${ }^{2}$ Diet containing $1 \%$ Zeolite coated with 25 ppm nanosilver; ${ }^{3}$ Diet containing $1 \%$ Zeolite coated with 50 ppm nanosilver; ${ }^{4}$ Diet containing $1 \%$ Zeolite coated with 75 ppm nanosilver; ${ }^{5}$ Standard error of means.

Values with different superscripts in the same column for each section are significantly different $(p<.05)$.

Table 4. Effect of treatments on microflora of broilers on d 21 and 42 (log cfu/g) treatments Cecum lleum
E. coli Total anaerobes
E. coli Total anaerobes
Lactobacillus sp.

Day 21 of age

\begin{tabular}{|llllll|}
\hline C & $9.23^{\mathrm{a}}$ & $7.93^{\mathrm{a}}$ & $7.73^{\mathrm{a}}$ & 8.28 & $7.21^{\mathrm{c}}$ \\
\hline $\mathrm{Z}^{1}$ & $8.73^{\mathrm{ab}}$ & $8.40^{\mathrm{a}}$ & $6.28^{\mathrm{b}}$ & 7.50 & $7.78^{\mathrm{bc}}$ \\
\hline${\mathrm{NS} 25^{2}}$ & $8.44^{\mathrm{b}}$ & $8.16^{\mathrm{a}}$ & $5.88^{\mathrm{b}}$ & 7.58 & $8.14^{\mathrm{ab}}$ \\
\hline $\mathrm{NS50}^{3}$ & $8.31^{\mathrm{b}}$ & $5.73^{\mathrm{b}}$ & $5.70^{\mathrm{b}}$ & 7.17 & $8.71^{\mathrm{a}}$ \\
\hline $\mathrm{NS75}^{4}$ & $8.12^{\mathrm{b}}$ & $8.28^{\mathrm{a}}$ & $5.10^{\mathrm{b}}$ & 7.60 & $8.15^{\mathrm{ab}}$ \\
\hline SEM $^{5}$ & 0.221 & 0.470 & 0.420 & 0.313 & 0.244 \\
\hline P-value & .019 & .012 & .003 & .215 & .015 \\
\hline Day 42 of age & & & & $8.31^{\mathrm{c}}$ \\
\hline C & $7.83^{\mathrm{a}}$ & $9.38^{\mathrm{a}}$ & $7.41^{\mathrm{a}}$ & $8.47^{\mathrm{a}}$ & $8.70^{\mathrm{bc}}$ \\
\hline $\mathrm{Z}^{1}$ & $6.96^{\mathrm{ab}}$ & $8.14^{\mathrm{b}}$ & $6.47^{\mathrm{ab}}$ & $8.04^{\mathrm{a}}$ & $9.13^{\mathrm{ab}}$ \\
\hline NS25 & $6.77^{\mathrm{ab}}$ & $8.06^{\mathrm{b}}$ & $6.63^{\mathrm{ab}}$ & $7.87^{\mathrm{a}}$ & $9.52^{\mathrm{a}}$ \\
\hline NS50 & $6.25^{\mathrm{bc}}$ & $8.02^{\mathrm{b}}$ & $6.25^{\mathrm{ab}}$ & $7.57^{\mathrm{a}}$ & $8.76^{\mathrm{bc}}$ \\
\hline NS75 & $5.14^{\mathrm{c}}$ & $7.61^{\mathrm{b}}$ & $4.93^{\mathrm{b}}$ & $4.34^{\mathrm{b}}$ & 0.220 \\
\hline SEM & 0.470 & 0.204 & 0.523 & 0.342 & .014 \\
\hline P-value & .010 & $<.0001$ & .041 & $<.0001$ & \\
\hline
\end{tabular}

${ }^{1}$ Diet containing $1 \%$ Zeolite; ${ }^{2}$ Diet containing $1 \%$ Zeolite coated with 25 ppm nanosilver; ${ }^{3}$ Diet containing $1 \%$ Zeolite coated with 50 ppm nanosilver; ${ }^{4}$ Diet containing $1 \%$ Zeolite coated with 75 ppm nanosilver; ${ }^{5}$ Standard error of means. 
Values with different superscripts in the same column for each section are significantly different $(p<.05)$.

Table 5. Effect of treatments on $\mathrm{H} / \mathrm{L}$ ratio, antibody titer against Newcastle $(\mathrm{HI})$ and Gumboro of broilers

\begin{tabular}{|llllll|}
\hline treatments & $\begin{array}{l}\text { H/L ratio } \\
\text { Day 28 of } \\
\text { age }\end{array}$ & $\begin{array}{l}\text { H/L ratio } \\
\text { Day 35 of } \\
\text { age }\end{array}$ & $\begin{array}{l}\text { H/L ratio } \\
\text { Day 42 of } \\
\text { age }\end{array}$ & $\begin{array}{l}\text { Newcastle Day 14 of } \\
\text { age }\end{array}$ & $\begin{array}{l}\text { Gumboro } \\
\text { Day 21 of } \\
\text { age }\end{array}$ \\
\hline $\mathrm{C}$ & $0.24^{\mathrm{b}}$ & $0.27^{\mathrm{b}}$ & 0.33 & 3.70 & $427.50^{\mathrm{a}}$ \\
\hline $\mathrm{Z}^{1}$ & $0.25^{\mathrm{b}}$ & $0.30^{\mathrm{b}}$ & 0.33 & 4.10 & $418.50^{\mathrm{a}}$ \\
\hline $\mathrm{NS} 25^{2}$ & $0.25^{\mathrm{b}}$ & $0.31^{\mathrm{ab}}$ & 0.33 & 4.10 & $396.25^{\mathrm{ab}}$ \\
\hline $\mathrm{NS} 50^{3}$ & $0.30^{\mathrm{a}}$ & $0.34^{\mathrm{a}}$ & 0.36 & 4.50 & $372.25^{\mathrm{b}}$ \\
\hline $\mathrm{NS} 75^{4}$ & $0.29^{\mathrm{a}}$ & $0.30^{\mathrm{ab}}$ & 0.35 & 4.10 & $372.75^{\mathrm{b}}$ \\
\hline $\mathrm{SEM}{ }^{5}$ & 0.011 & 0.015 & 0.010 & 0.321 & 11.009 \\
\hline$P$-value & .0004 & .021 & .160 & .454 & .0088 \\
\hline
\end{tabular}

${ }^{1}$ Diet containing $1 \%$ Zeolite; ${ }^{2}$ Diet containing $1 \%$ Zeolite coated with 25 ppm nanosilver; ${ }^{3}$ Diet containing $1 \%$ Zeolite coated with 50 ppm nanosilver; ${ }^{4}$ Diet containing $1 \%$ Zeolite coated with 75 ppm nanosilver; ${ }^{5}$ Standard error of means.

Values with different superscripts in the same column for each section are significantly different $(p<.05)$. 


\begin{tabular}{|llll|}
\hline \multicolumn{4}{|l|}{ Table 6. Effect of treatments on the amount of immunoglobulins of plasma (mg/ml) on d 42} \\
\hline treatments & $\mathbf{l g A}$ & $\mathbf{l g M}$ & $\mathbf{l g Y}$ \\
\hline $\mathrm{C}$ & $0.480^{\mathrm{a}}$ & 0.091 & $0.552^{\mathrm{a}}$ \\
\hline $\mathrm{Z}^{1}$ & $0.472^{\mathrm{a}}$ & 0.083 & $0.508^{\mathrm{a}}$ \\
\hline $\mathrm{NS} 25^{2}$ & $0.350^{\mathrm{b}}$ & 0.078 & $0.324^{\mathrm{b}}$ \\
\hline $\mathrm{NS} 50^{3}$ & $0.280^{\mathrm{bc}}$ & 0.070 & $0.342^{\mathrm{b}}$ \\
\hline $\mathrm{NS} 75^{4}$ & $0.234^{\mathrm{c}}$ & 0.073 & $0.256^{\mathrm{b}}$ \\
\hline $\mathrm{SEM}{ }^{5}$ & 0.043 & 0.061 & 0.032 \\
\hline$P$-value & .0002 & .360 & $<.0001$ \\
\hline
\end{tabular}

${ }^{1}$ Diet containing 1\% Zeolite; ${ }^{2}$ Diet containing $1 \%$ Zeolite coated with 25 ppm nanosilver; ${ }^{3}$ Diet containing $1 \%$ Zeolite coated with 50 ppm nanosilver; ${ }^{4}$ Diet containing $1 \%$ Zeolite coated with 75 ppm nanosilver; ${ }^{5}$ Standard error of means.

Values with different superscripts in the same column for each section are significantly different $(p<.05)$.

\section{Figures}

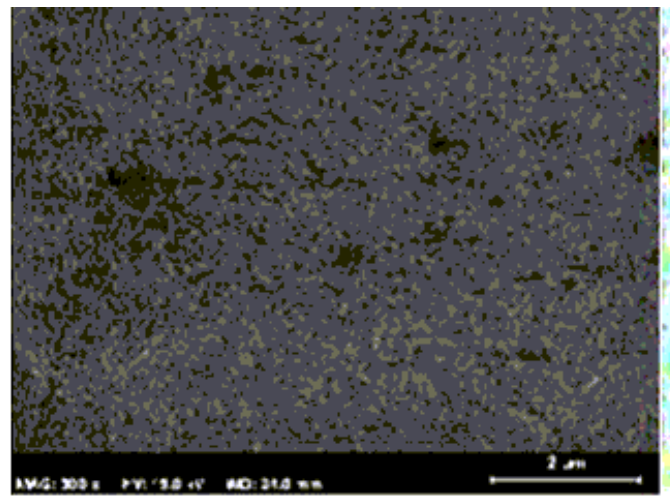

FESEM image

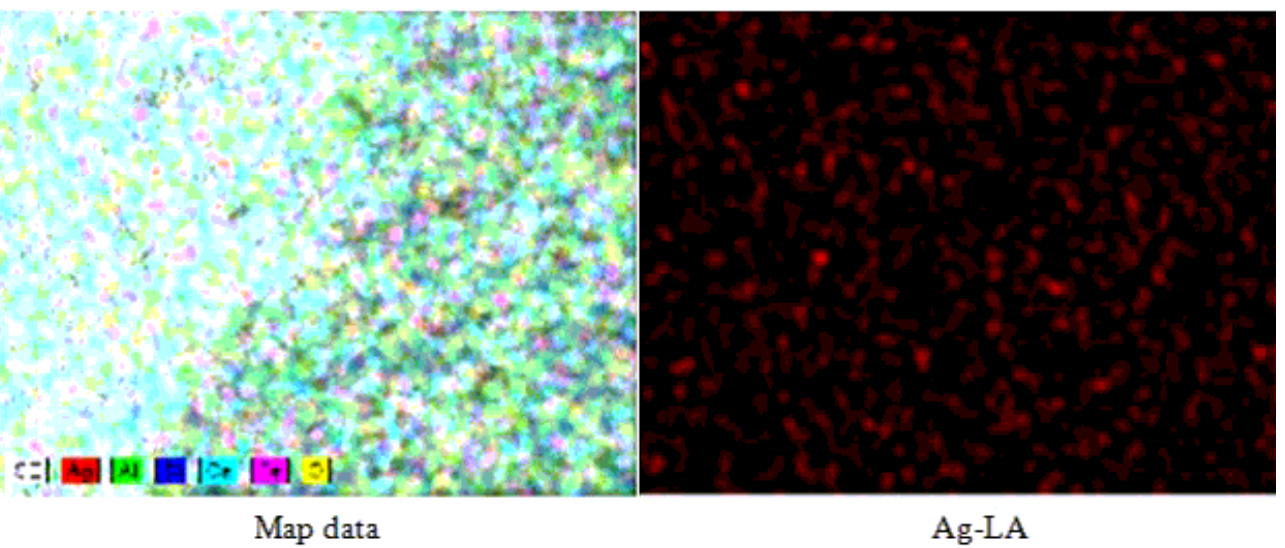

Ag-LA

\section{Figure 1}

Field emission scanning electron microscopy (FESEM) micrographs for morphology studied and energy dispersive X-ray spectroscopy (EDX) for elemental map-ping analyses and materials composition of the Ag-NPs coated on zeolite. 


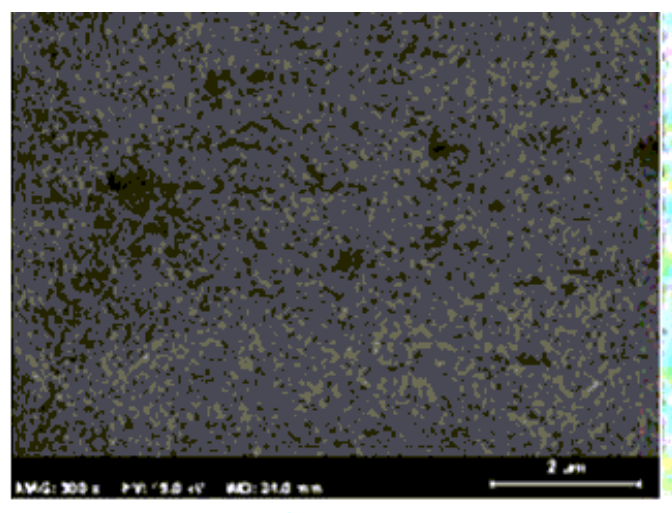

FESEM image

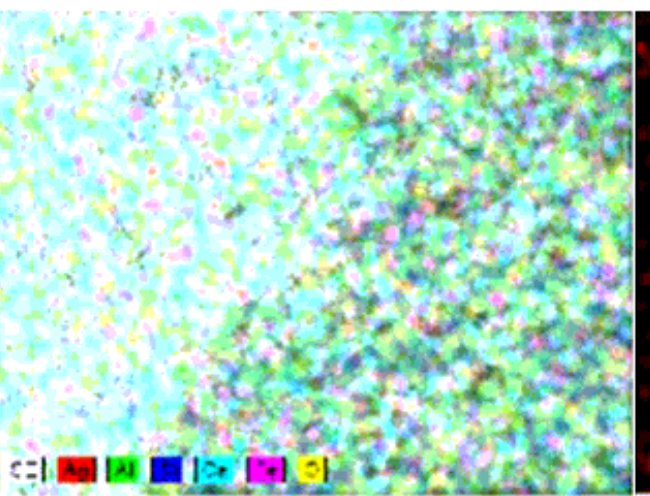

Map data

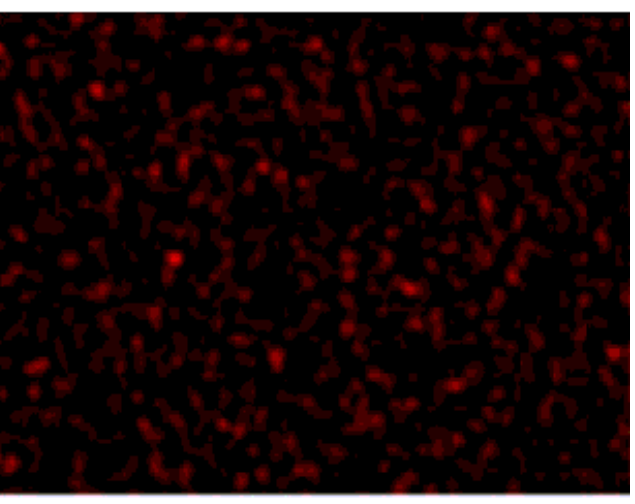

Ag-LA

\section{Figure 1}

Field emission scanning electron microscopy (FESEM) micrographs for morphology studied and energy dispersive X-ray spectroscopy (EDX) for elemental map-ping analyses and materials composition of the Ag-NPs coated on zeolite. 